\title{
Dissodactyluscrinitichelis Moreira, 1901 and Leodia sexiesperforata (Leske, 1778): first record of this symbiosis in Brazil
}

Vinicius Queiroz, Licia Sales, Elizabeth Neves and Rodrigo Johnsson

LABIMAR (Crustacea, Cnidaria \& Fauna Associada), Universidade Federal da Bahia. Avenida Adhemar de Barros s/no, Campus Ondina. CEP 40170- 290. Salvador, BA, Brazil. E-mail: (VQ) vinicius_ufba@yahoo.com.br; (LS) licia_so@yahoo.com.br; (EN) elizabeth.neves@gmail.com; (RJ) r.johnsson@gmail.com

Abstract

The crabs of the genus Dissodactylus are well known as ectosymbionts of irregular echinoids belonging to Clypeasteroida and Spatangoida. Dissodactylus crinitichelis is the only species of the genus reported in Brazil. The pea crab species has been already recorded associated with four species of echinoids in Brazilian waters. This paper reviews the known hosts for $D$. crinitichelis and registers for the first time the association between the pea crab and the sand dollar Leodia sexiesperforata increasing to five the number of known hosts for the crab.

Key Words: Ecological association, ectosymbiont, Pinnotheridae.

\section{Introduction}

The diversity of the marine environment, specially the benthic substratum is commonly reflected by many interactions among organisms, even free living ones. Such event is quite common since many of these species act as substratum or environment for others. The existence of many organisms living in association and their close relation allows for the emergence of symbiotics relationships (Thiel et al., 2003; Rohde, 2005; Baeza, 2007). Symbiosis, sensu De Bary (1879), can be defined as "a phenomenon in which dissimilar organisms live together" (Vermeij, 1983; Paracer and Ahmadjian, 2000). These interactions are commonly observed among crustaceans. Therefore, these taxa have many species that have adapted to co-exist in symbiosis with other invertebrates (Barel and Kramers, 1977; Rohde, 2005).

The Pinnotheridae De Haan, 1833 includes about 302 species of little crabs (Ng et al., 2008) highly specialized in living in close association with other invertebrates. The family is known for their association with various invertebrate taxa, such as molluscs, polychaetes, ascidians, crustaceans or echinoderms (holothurians and irregular echinoids) (Schmitt et al., 1973; Powers, 1977; Williams, 1984; Takeda et al., 1997; Thoma et al., 2005, 2009; Ahyong and Ng, 2007). However the pinnotherids are also capable of showing a short free-living stage (first crab stage) (Christensen and McDermott, 1958).

Among the 54 genera of Pinnotheridae, Dissodactylus (Smith, 1870) (Ng et al., 2008; $\mathrm{Ng}$ and van Tri, 2010) is known as an ectosymbiont of irregular echinoids (Griffith, 1987a). The genus is characterized by a discontinuous anterolateral margin of the carapace, delicate, ventrally curved labium, epistome dorsoventrally reduced, and subrectangular, medially directed ischiummerus of the third maxilliped (Griffith, 1987a; 
Campos and Griffith, 1990). The distribution of Dissodactylus is restricted to the New World, ranging in the western Atlantic Ocean from Massachusetts (USA) to Argentina, with four species recorded, and in the eastern Pacific from Mexico to Peru, where five species are known (Rathbun, 1918; Schmitt et al., 1973; Werding and Sanchez, 1989; Martins and D’lncao, 1996; Fumis et al., 2006). However, so far, there are no common records between the Pacific and Atlantic regions (Griffith, 1987a; Campos and Griffith, 1990).

The crab Dissodactylus crinitichelis Moreira, 1901 is typical of the western Atlantic, ranging from the USA to Argentina (Rathbun, 1918, (as D. encopei); Martins and D'lncao, 1996; Fumis et al., 2006). It has been observed maintaining symbiotic relationships with several species of irregular echinoids, such as the spatangoid Meoma ventricosa (Lamarck, 1816) and the clypeasteroids Encope emarginata (Leske, 1778); E. michelini Agassiz, 1841; Clypeaster subdepressus (Gray, 1825); and Leodia sexiesperforata (Leske, 1778) (Rathbun, 1918; Telford, 1978; 1982; Campos and SolísMarín, 1998; Wirtz et al., 2009).

In Brazil, the first report of an association with $D$. crinitichelis was provided by Coelho and Ramos-Porto (1995) for Encope sp.; Martins and D'lncao (1996) cited the associations of the crab with E. emarginata, Mellita sp., Clypeaster sp. and Luidia sp.; finally, Wirtz et al. (2009) mentioned the relationship with Meoma ventricosa in Espirito Santo State.

Previous records show that the sand dollar Leodia sexiesperforata is restricted to the Americas, ranging from North Carolina (USA) to Uruguay (Telford and Mooi, 1986). Along the Brazilian coast there are records from Paraiba to Rio de Janeiro (Alves and Cerqueira, 2000; Magalhães et al., 2005; Ventura et al., 2006; 2007; Gondim et al., 2008; Manso et al., 2008). Despite this geographical distribution, all reports of the association of $D$. crinitichelis with this irregular echinoid are restricted to the Caribbean (Telford, 1978; 1982 - Rockley Beach, Bridgetown, Barbados - 1304'24”N, 59³5'18”'W; Campos and Solis-Marin, 1998

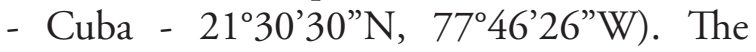

aim of this paper is to report the association between Dissodactylus crinitichelis and Leodia sexiesperforata for the first time outside the Caribbean, specifically for Brazil.

\section{Material and Methods}

Sampling was carried out on May $13^{\text {th }}$, 2010 at the Porto da Barra beach, Salvador - BA, Brazil (1300'24”S - 38³1'48”W). Specimens of Leodia sexiesperforata were obtained by free diving in the subtidal zone. Only a single specimen of the sand dollar showed an associated pea crab. The host and the symbiont were photographed and immediately placed in a plastic bag containing sea water and then taken to the laboratory. Posteriorly they were photographed and fixed in $70 \%$ ethanol. The material was deposited in the Crustacean Collection of the Museu de Zoologia da Universidade Federal da Bahia (UFBA 430)

\section{Results and Discussion}

\section{Dissodactylus crinitichelis Moreira, 1901}

(Fig. 1F)

Dissodactylus crinitichelis Moreira, 1901. - Rathbun, 1933: 83. - Rodrigues da Costa, 1969: 260. - Coelho and Ramos, 1972: 196. - Fenucci, 1975:172. - Powers, 1977:1 20. - Williams, 1984:438. - Melo, 1985:1 23. Abele and Kim, 1986:64. - Griffith, 1987:412. - Martins and D'incao, 1996: 4. - Campos and Solís-Marín, 1998: 330. - Almeida et al., 2010: 358.

Dissodactylus encopei; Rathbun, 1901: 22. - Rathbun 1918: 119. - Williams, et al., 1968:56.

Dissodactylus crinitichelis is characterized by an almost flat carapace that shows a smooth surface. The length to width ratio of the carapace is $0.75: 1$. The third maxilliped covers the oral cavity completely. The propodus shows a small 
dactyl and articulates in the second half of the inferior margin. The pereopods are short and strong. Outer maxilliped palp is 3-segmented. Telson forms an equilateral triangle. Females bear all abdominal segments distinct. All these characteristics confirm the identification of the specimen provided by the literature (Morreira, 1901; Rathbun, 1918; Martins and D'lncao, 1996). A relevant point, according to Griffith (1987a), is the similarity of D. crinitichelis and D. latus Griffith, 1987. However, according to the same author, the mean width to length ratio of carapace provides enough bases to distinguish both species $(1.43 \pm 0.03 D$. crinitichelis and $1.66 \pm 0.05$ to D. latus).

\section{Leodia sexiesperforata (Leske, 1778)}

(Figs. $1 \mathrm{~A}-\mathrm{E}$ )

Echinodiscus sexies perforatus Leske, 1778: 199. Scutella sexforis Lamarck, 1816: 9. Desmoulins, 1837: 70.

Mellita hexapora Agassiz, 1841: 41. - Agassiz and Desor, 1846: 138.

Mellita similis Agassiz, 1841: 43.

Leodia richardsonii Gray, 1851: 36.

Mellita erythraea Gray, 1851: 36.

Mellita sexiesperforata Bernasconi, 1941: 107. Mellita platensis: Bernasconi, 1947: 117.

The sand dollar Leodia sexiesperforata (Leske, 1778) can be identified by the presence of six closed, narrow and elongated lunules (five ambulacrals and one interambulacral). The testis is compressed in the oral/aboral axis and shows five shorts and equal petaloids and four gonopores in the apical system. Color ranges from yellow to light brown (Goodbody, 1960; Serafy, 1979; Hendler et al., 1995; Manso et al., 2008). The specimen of $L$. sexiesperforata has $58.2 \mathrm{~mm}$ in diameter, while the known diameter ranges from 22 to $110 \mathrm{~mm}$ (Goodbody, 1960; Serafy, 1979; Hendler et al., 1995). A male specimen of D. crinitichelis, with $3.2 \mathrm{~mm}$ width and 2.6 $\mathrm{mm}$ length, was found clinging to the oral side, close to the anterior lunules (Fig. 1F). The position of the crab on the host may be explained as an evidence of its survival strategy due to its mode of living.

The family Pinnotheridae is usually considered as parasitic or at least semiparasitic. In this context, the dactyli bifid seem adequate, because they have no clear change in morphology to adapt themselves to a parasitic lifestyle (Telford, 1978). Dissodactylus crinitichelis is always characterized as irregular urchin's symbiont, however there are very few studies clarifying the correct association of the species and its sand dollar hosts.

Pohle and Telford (1981) state that $D$. crinitichelis is an obligate parasite because it requires a nearby host to complete its larval development. However, the authors also say that sub-adults and adults stages seem to be facultative parasites. In a subsequent study, Telford (1982a), based on cheliped morphology, stomach contents of the pea crabs and spine allometry of sand dollars, defines the relationship as parasitism, showing that approximately $80 \%$ of the food obtained by the crab comes from the host.

However studies carried out by these authors (Pohle and Telford, 1981; Telford, 1982a) are exclusively based on data from L. sexiesperforata as a single host. Since $D$. crinitichelis is recorded as symbiont of four other species of irregular sea urchins (M. ventricosa, E. emarginata, E. michelini, C. subdepressus), it is important to investigate firstly if there is a preference of the pea crab for one of the sand dollars and secondly whether $D$. crinitichelis has the same behavior with other hosts.

Gray et al. (1968) studied the relation of D. mellitae (Rathbun, 1900) with different echinoderm hosts and observed that the crab preferred E. michelini rather than Mellita quinquiesperforata (Leske, 1778). Subsequently Dexter (1977) noted the same pattern when studying $D$. nitidus Smith, 1870, which opted by Mellitella stokesii (L. Agassiz, 1841). Unfortunately there are not many studies with D. crinitichelis and its biology (Telford, 1978) and the very few ones deals with other hosts than L. sexiesperforata. In this panorama it is very difficult make further inferences on the 
preference of this pea crab.

The analysis of the association records with the sand dollars along the Brazilian coast reveals that $D$. crinitichelis is mainly associated with the Encope emarginata and Meoma ventricosa (Martins and D'lncao, 1996; Wirtz et al., 2009; Almeida et al., 2010). Additionally, Coelho and Ramos-Porto (1995) mentioned Encope sp. as a host in Tamandaré, Pernambuco State. However the genus Encope in Brazil is restricted to a single species, $E$. emarginata, which occurs from Pernambuco to Rio Grande do Sul State (Tommasi, 1999; Netto et al., 2005; Capítoli and Bemvenuti, 2006; Lima and Fernandes, 2009; Oliveira et al., 2010). Thus, it is possible to deduce that the record of Coelho and Ramos-Porto (1995) may also refer to E. emarginata.

Martins and D'lncao (1996) also included the genera Mellita, Clypeaster and Luidia among potential hosts for $D$. crinitichelis but the specimens have not been identified further than the generic level. However as Luidia Forbes, 1839 belongs to Asteroidea its record as host for pea crabs is extremely unusual since Dissodactylus are characterized by their specific association with irregular echinoids (sand dollars and heart urchins) (Griffith, 1987a; Telford, 1982).

The genus Mellita is represented in Brazil by a single species, $M$. quinquiesperforata (Leske, 1778), which has a wide distributional range along the Brazilian coast, occuring from Pará to Rio Grande do Sul State (Matos et al., 2000; Barros et al., 2001; Netto et al., 2005). Consequently the record of Martins and D'lncao (1996) can be possibly attributed to this host species.

However, according to Tommasi (1999) eight species of Clypeaster have been recorded in Brazil. C. subdepressus (Gray, 1825) is the species with the widest distribution. Records along the Brazilian coast expand from Bahia to Southern Brazil (Krau, 1956; Alves and Cerqueira, 2000; Magalhães et al., 2005; Netto et al., 2005; Vellutini and Migoto, 2010; Xavier, 2010). Because of the range of this irregular echinoid it is possible to assume that $C$. subdepressus was the species observed by Martins and D'lncao (1996).

According to Tommasi (1999), six genera and fourteen species belonging to Clypeasteroidea Agassiz, 1872 have been registered along the Brazilian coast. Clypeaster is the largest genus with eight species whereas the others have only one species each. For Spatangoidea Claus, 1876 there are records of seven genera, each one with a single species. These two taxa (Clypeasteroidea and Spatangoidea) are the most important hosts for the species of Dissodactylus since the literature indicates the restriction of the association of these crabs to sand dollars and heart urchins (Rathbun, 1918; Telford, 1978; 1982; Griffith, 1987a; Campos and Solís-Marín, 1998; Wirtz et al., 2009).

Previous works indicate that the association between $D$. crinitichelis and irregular echnoids (clypeasteroids and spatangoids) has a register of five host species (Rathbun, 1918; Schmitt et al., 1973 Telford, 1978; 1982; Campos and Solís-Marín, 1998; Wirtz et al., 2009). In Brazil there are only four known hosts so far (Coelho and Ramos-Porto, 1995; Martins and D'lncao, 1996; Wirtz et al., 2009). This paper increases the number of host-species for $D$. crinitichelis to five, after adding the record of $L$. sexiesperforata.

Leodia sexiesperforata is found preferably in biogenic sands (Telford and Mooi, 1986) and the geographic distribution of this sand dollar extends as far as Argentina (Bernasconi, 1941; 1947 (as M. platensis); Telford and Mooi, 1986; Alves and Cerqueira, 2000; Magalhães et al., 2005; Ventura et al., 2006; 2007; Gondim et al., 2008; Manso et al., 2008). Reports of the relationship of these two species are restricted to Caribbean waters (Telford, 1978; 1982; Telford an Mooi, 1986; Campos and SolisMarin, 1998), consequently, this association is restricted to the Tropical Province (Palacio, 1980). Despite that the distribution of both species $D$. crinitichelis and $L$. sexiesperforata ranges to Argentina, (Patagonic Province) this association had not been registered out of Tropical Province yet (Palacio, 1980). 


\section{Acknowledgments}

We would like to thank specially to Dr. Ernesto Campos (Facultad de Ciencias U.A.B.C., Mexico) and an anonymous reviewer for the helpful collaboration and important suggestions. This study was supported by CNPQ (Conselho Nacional de Desenvolvimento Científico e Tecnológico) and FAPESB (Fundação de Amparo a Pesquisa na Bahia).

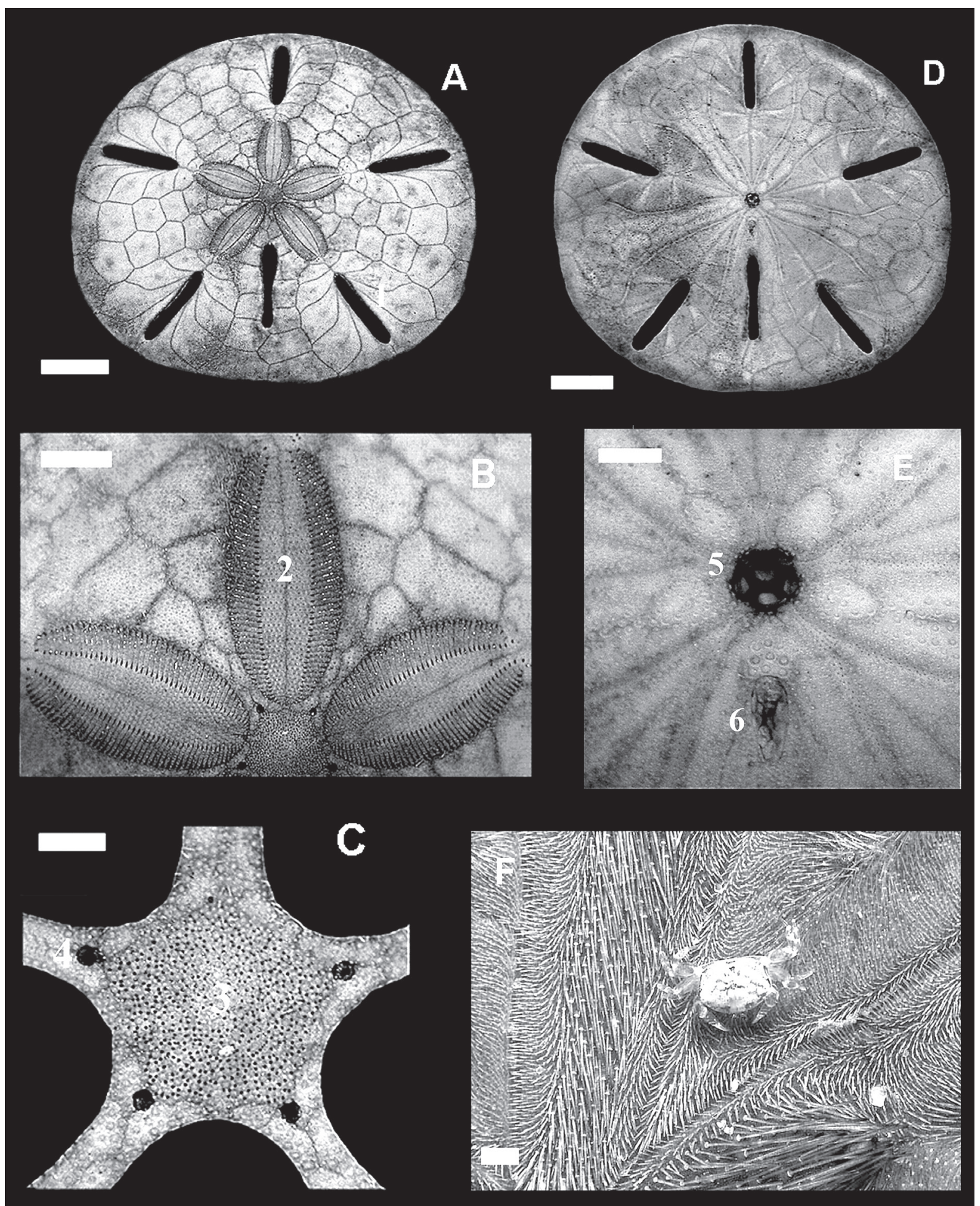

Figure 1. Leodia sexiesperforata. A, B and C - Aboral view showing lunules (1), petaloids (2), madreporite (3) and gonopores (4). D and E - Oral view showing mouth (5) and anus (6). F - Photo in situ of Dissodactylus crinitichelis in symbiosis with L. sexiesperforata. Scale bars: A and D = 10 $\mathrm{mm} ; \mathrm{B}=2.5 \mathrm{~mm} ; \mathrm{C}=1 \mathrm{~mm} ; \mathrm{E}=2 \mathrm{~mm} ; \mathrm{F}=1.5 \mathrm{~mm}$. 


\section{References}

Abele, L. G. and Kim, W. 1986. An illustrated Guide to the Marine Decapod Crustaceans of Florida. Technical Series. State of Florida Department of Environmental Regulation, 8: $1-391$.

Agassiz, L. 1841. Monographies d'Echinoderms vivans et fossilis, des scutelles. $151 \mathrm{p}$.

Agassiz, L. and Desor, E. 1846. Catalogue raisonné des familles des genres et des espèces de la Classe de Echinodermes. Annales des Sciences Naturelles, Zoologie 3(6): 325-374.

Ahyong, S.T. and Ng, P.K.L. 2007. The pinnotherid type material of Semper (1880), Nauck (1880) and Bürger (1895) (Crustacea: Decapoda: Brachyura). The Raffles Bulletin of Zoology, 16(Suplement): 191-226.

Alexander, D. E. and Ghiould, J. 1980. The functional significance of the lunules in the sand dollar, Mellita quinquiesperforata. Biological Bulletin, 159: 561-570.

Almeida, A.O; Souza, G.B.G.; Boehs, G. and Bezerra, L.E.A. 2010. Shallow-water anomuran and brachyuran crabs (Crustacea: Decapoda) from southern Bahia, Brazil. Latin American Journal of Aquatic Research, 38(3): 329-376.

Alves, O.F.S. and Cerqueira, W.R.P. 2000. Echinodermata das praias de Salvador (Bahia, Brasil). Revista Brasileira de Zoologia, 17(2): 543-553.

Baeza, J.A. 2007. The origins of symbiosis as a lifestyle in marine crabs (genus Petrolisthes) from the eastern Pacific: Does interspecific competition play a role? Revista de Biologia Marina y Oceanografía, 42(1): 7-21.

Barel, G.D.N. and Kramers, P.G.N. 1977. A survey of the echinoderm associates of the north-east Atlantic area. Zoologische Verhandelingen, 156: 3-159.

Barros, F.; Borzone, C.A. and Rosso, S. 2001. Macroinfauna of six beaches near Guaratuba bay, southern Brazil. Brazilian Archives of Biology and Technology, 44(4): 351-364.

Bernasconi, I. 1941. Sobre la distribución geográfica de "Mellita sexiesperforata" (Leske), Physis, 19: 106-108.

Bernasconi, I. 1947. Una nueva especie de "Mellita" en la República Argentina. Physis, 20: 117-118.
Campos, E. and Griffith, H. 1990. Clypeasterophilus, a new genus to receive the small-palped species of the Dissodactylus complex (Brachyura: Pinnotheridae). Journal of Crustacean Biology, 10(3): 550-553.

Campos, E. and Solís-Marín, F. 1998. New Records of Crabs (Pinnotheridae) Symbiotic with Irregular Echinoids in Cuba. Caribbean Journal of Science, 34(3-4): 329-330.

Capítoli, R. and Bemvenuti, C. 2006. Associaçóes de macroinvertebrados bentônicos de fundos inconsolidados da plataforma continental e talude superior no extremo sul do Brasil. Atlântica, 28(1): 47-59.

Coelho, P.A. and Ramos, M.A. 1972. A constituição e a distribuição da fauna de Decápodes do litoral leste da América do Sul entre as latitudes de $5^{\circ} \mathrm{N}$ e $39^{\circ} \mathrm{S}$. Trabalhos oceanográficos da Universidade Federal de Pernambuco, 13: 133-236.

Coelho, P.A. and Ramos-Porto, M. 1995. Crustáceos da Região de Tamandaré, estado de Pernambuco, Brasil. Boletim Técnico Cientifico do CEPENE, 3(1): 49-56.

Christensen, A.M. and McDermott, J.J. 1958. Life-history and biology of the oyster crab, Pinnotheres ostreum Say. Biological Bulletin, 114: 146-179.

de Bary, A. 1879. The Phenomenon of Symbiosis. Privately printed in Strasburg. 30p.

Fenucci, J.L. 1971. Notas sobre las dos especies de Pinnotheres mas communesen el litoral bonaerense (Decapoda, Brachyura, Pinnotheridae). Physis, 30(81): 355-367.

Fumis, P.B.; Fransozo, A.; Bertini, G.; Braga, A.A. and Pie, M.R. 2006. Growth rate of the crab Dissodactylus crinitichelis Moreira, 1901 (Crustacea: Decapoda: Pinnotheroidea) under laboratory conditions. Proceedings of the Biological Society of Washington, 119(3): 395-403.

Gondim, A.I.; Lacouth, P.; Alonso, C. and Manso, C.L.C. 2008. Echinodermata da Praia do Cabo Branco, João Pessoa, Paraíba, Brasil. Biota Neotropica, 8(2): 151-159.

Goodbody, I. 1960. The feeding mechanism in the sand dollar, Mellita sexiesperforata (Leske). Biological Bulletin, 119: 80-86.

Gray, J. E. 1851. Description of two new genera and some new species of Scutellidae and Echinolampidae in the collection of the British Museum. Proceedings of the Zoological 
Society of London, 9: 34-38.

Griffith, H. 1987a. Taxonomy of the genus Dissodactylus (Crustacea: Brachyura: Pinnotheridae) with descriptions of three new species. Bulletin of Marine Science, 40(3): 397-422.

Griffith, H. 1987b. Phylogenetic relationships and evolution in the genus Dissodactylus Smith, 1870 (Crustacea: Brachyura: Pinnotheridae). Canadian Journal of Zoology, 65(9): 2292-2310.

Hendler, G.; Miller, I.E.; Pawson, D.L. and Kier, P.M. 1995. Sea stars, sea urchins, and alliens: Echinoderms of Florida and the Caribbean. Washington D. C., Smithsonian Institution Press, 391p.

Lima, E.J.B. and Fernandes, M.L.J. 2009. Diversidade de equinodermos (Echinodermata) no Estado de Pernambuco (Brasil). Zoociências, 11(1): 55-63.

Krau, L. 1956. A existência de Clypeaster latisimus (Lamarck) no Brasil e consideraçóes sobre Clypeaster subdepressus (Gray) (Clypeasteroida, Echinoidessa). Memórias do Instituto Oswaldo Cruz, 54: 413-426.

Lamarck, J.B.P.A. 1816. Echinides. In: Histoire Naturelle des Animaux sans Vertèbres. 3: 1-59.

Leske, N.G. 1778. Additamenta ad Jacobi Theodori Klein Naturalem Dispositionem Echinodermatum et Lucubratiunculam de Aculeis Echinorum Marinorum. 216p.

Magalhães, W.F.; Martins, L.R. and Alves, O.F.S. 2005. Inventário dos Echinodermata do Estado da Bahia. Brazilian Journal of Aquatic Science and Technology, 9(1): 61-65.

Manso, C.L.C.; Alves, O.F.S. and Martins, L.R. 2008. Echinodermata da Baía de Todos os Santos e da Baía de Aratu (Bahia, Brasil). Biota Neotropica, 8: 180-196.

Martins, S.T.S. and D'incao, F. 1996. Os Pinnotheridae de Santa Catarina e Rio Grande do Sul, Brasil (Decapoda, Brachyura). Revista Brasileira de Zoologia, 13: 1-26.

Matos, E.; Matos, P.; Corral, L. and Azevedo, C. 2000. Estrutura fina do espermatozóide de Mellita quinquiesperforata Leske (Echinodermata) do litoral norte do Brasil. Revista Brasileira de Zoologia, 17: 741-745.

Melo, G.A.S. 1971. Duas novas espécies de Pinnotheridae (Crustacea, Brachyura) no litoral brasileiro. Papéis avulsos de Zoologia,
23(22): 197-203.

Moreira, C. 1901. Crustáceos do Brasil. Archivos do Museu Nacional do Rio de Janeiro, 11: $1-151$.

Netto, L.F.; Hadel, V.F. and Tiago, C.G. 2005. Echinodermata from São Sebastião Channel (São Sebastião, São Paulo, Brazil). Revista de Biologia Tropical, 53(3): 207-218.

Ng, P.K.L.; Guino, D. and Davie, P.J.F. 2008. Systema Brachyurorum: Part I. An annotated checklist of extant brachyuran crabs of the world. Raffles Bulletin of Zoology, 17: 1-286.

Ng, P.K.L. and van Tri, N. 2010. Solenotheres prolixus, a new genus and new species of pinnotherid crab (Crustacea: Decapoda: Brachyura) associated with the razor clam, Solen corneus Lamarck, 1818 (Solenidae) in Vietnam. Zootaxa, 2570: 61-68.

Oliveira, J.P.; de Oliveira, J. and Manso, C.L.S. 2010. Inventário da coleção de equinodermos do LABIMAR, Campus Profo. Alberto Carvalho, Universidade Federal de Sergipe. Scientia Plena, 6(12): 1-14.

Palacio, F.J. 1980. Revisión zoogeográfica marina del sur del Brasil. Boletim do Instituto Oceanográfico, 31(1): 69-92.

Paracer, S. and Ahmadjian, V. 2000. Symbiosis: An Introduction to Biological Associations. Oxford University Press, 304p.

Pohle, G. and Telford, M. 1981. The larval development of Dissodactylus crinitichelis Moreira, 1901 (Brachyura: Pinnotheridae) in laboratory culture. Bulletin of Marine Science, 31(3): 753-773.

Powers, L.W. 1977. A catalogue and bibliography to the crabs (Brachyura) of the Gulf of Mexico. Contributions in Marine Sciences, 20 (Suppl.): 1-190.

Rathbun, M.J. 1901. The Brachyura and Macrura of Porto Rico. U. S. Commission of Fish and Fisheries Bulletin, 20: 1-127.

Rathbun, M.J. 1918. The Grapsoid crabs of America. Bulletin of the United States National Museum, 97: 1-461.

Rathbun, M.J. 1933. Brachyuran crabs of Porto Rico and the Virgin Islands. Scientific Survey of Porto Rico and Virgin Islands. New York Academy of Science, 15(2): 1-121.

Rodrigues da Costa, H. 1969. As espécies brasileiras da família Pinnotheridae (Crustacea, Reptantia) com descrição de uma nova espécie (Fábia sebastianensis). Trabalhos 
oceanográficos da Universidade Federal de Pernambuco, 9(11): 255-264.

Rohde, K. 2005. Marine Parasitology. Csiro Publishing National Library of Australia. 590p.

Schmitt, W.L.; Mccain, J.C. and Davidson, E.S. 1973. Crustaceorum Catalogus Pars 3. Decapoda I. Brachyura I. Fam. Pinnotheridae W. Junk, Den Haag, 160p.

Serafy, D.K. 1979. Echinoids (Echinodermata: Echinoidea). Memoirs of the Hourglass Cruises (Florida Department of Natural Resources Marine Research Laboratory) 5(3): 1-120.

Takeda, S.; Tamura S. and Washio, M. 1997. Relationship between the pea crab Pinnixa tumida and its endobenthic holothurian host Paracaudina chilensis. Marine Ecology Progress Series, 149: 143-154.

Telford, M. 1978. Distribution of two species of Dissodactylus (Brachyura: Pinnotheridae) among their echinoid host population in Barbados. Bulletin of Marine Science, 28: 651-658.

Telford, M. 1982. Echinoderm spine structure, feeding and host relationships of four species of Dissodactylus (Brachyura: Pinnotheridae). Bulletin of Marine Science, 32: 584-594.

Telford, M. and Mooi, R. 1986. Resource partitioning by sand dollars in carbonate and siliceous sediments: Evidence from podial and particle dimensions. Biological Bulletin, 169: 431-448.

Thiel, M.; Zander, A.; Valdivia, N.; Baeza, J.A. and Rueffler, C. 2003. Host fidelity of a symbiotic porcellanid crab: the importance of host characteristics. Journal of Zoology, 261: 353-362

Thoma, B.P.; Heard, R.W and Vargas, R. 2005. A new species of Parapinnixa (Decapoda: Brachyura: Pinnotheridae) from Isla del Coco, Costa Rica. Proceedings of the Biological Society of Washington, 118(3): 543-550.

Thoma, B.P.; Heard, R.W. and Felder, D.L. 2009. Redescription of Pinnixa arenicola Rathbun, 1922 (Decapoda: Brachyura: Pinnotheridae), with new observations on its range and host. Proceedings of the Biological Society of Washington, 122(1): 72-80.

Tommasi, L.R. 1999. Echinodermatas recentes e fósseis do Brasil. Base de Dados Tropical. Campinas. Disponível na INTERNET via http://www.bdt.org.br/zoologia. Arquivo consultado em agosto de 2004.

Vellutini, B.C. and Migotto, A.E. 2010.

Embryonic, larval, and juvenile development

of the sea biscuit Clypeaster subdepressus (Echinodermata: Clypeasteroida). PloS ONE, 5(3): $1-15$.

Ventura, C.R.R.; Lima, R.P.N.; Nobre, C.C.; Veríssimo, I. and Zama, P.C. 2006. Filo Echinodermata. In: Lavrado, H.P. and Ignácio B.L. (eds), Biodiversidade bentônica da região central da Zona Econômica Exclusiva brasileira. Museu Nacional, Rio de Janeiro, (Série Livros, 18), 389p.

Ventura, C.R.R.; Veríssimo, I.; Nobre, C.C. and Zama, P.C. 2007. Filo Echinodermata. In: Lavrado, H.P. and M.S. Viana (eds), Atlas de invertebrados marinhos da região central da Zona Econômica Exclusiva brasileira, parte 1. Museu Nacional, Rio de Janeiro, (Série Livros, 25), 258p.

Vermeij, G.J. 1983. Intimate Associations and Coevolution in the Sea. p. 311-327. In: Futuyma, D.J. and Slatkin, M. (eds), Coevolution, Sinauer Associates, Sunderland.

Xavier, L.A.R. 2010. Checklist of Echinodermata in Santa Catarina State, Brazil. Brazilian Journal of Aquatic Science and Technology, 14(2): 73-78.

Werding, B. and Sanchez, H. 1989. Pinnotherid crabs of the genus Dissodactylus smith, 1870, associated with irregular sea urchins at the Caribbean coast of Colombia (Crustacea: Decapoda: Pinnotheridae). Zoologische Mededelingen, 63(4): 35-42.

Williams, A.B. 1984. Shrimps, Lobsters and Crabs of the Atlantic coast of the Eastern United States, Maine to Florida. Washington, Smithsonian Institution Press, 550 p.

Williams, A.B.; Mccloskey, L. and Gray, L. 1968. New records of Brachyuran Decapod Crustacea from the continental shelf of North Carolina, USA. Crustaceana, 15 (1): 41-66.

Wirtz, P.; Melo, G.A.S. and Grave, S. 2009. Symbioses of the decapod crustaceans along the coast of Espirito Santo, Brazil. Marine Biodiversity Records, United Kingdom, 2: 1-9.

Submitted 30 March 2011 Accepted 27 July 2011 